\title{
Immunotherapy with Allergen Peptides
}

\author{
Mark Larché, PhD
}

\begin{abstract}
Specific allergen immunotherapy (SIT) is disease-modifying and efficacious. However, the use of whole allergen preparations is associated with frequent allergic adverse events during treatment. Many novel approaches are being designed to reduce the allergenicity of immunotherapy preparations whilst maintaining immunogenicity. One approach is the use of short synthetic peptides which representing dominant $T$ cell epitopes of the allergen. Short peptides exhibit markedly reduced capacity to cross link IgE and activate mast cells and basophils, due to lack of tertiary structure. Murine pre-clinical studies have established the feasibility of this approach and clinical studies are currently in progress in both allergic and autoimmune diseases.
\end{abstract}

Key words: allergy, epitope, IL-10, immunological tolerance, immunotherapy, peptide, regulatory $T$ cell, $T$ cell

Secific allergen immunotherapy (SIT) is disease $S$ modifying and efficacious. However, the use of whole-allergen preparations is associated with frequent allergic adverse events during treatment. Many novel approaches are being designed to reduce the allergenicity of immunotherapy preparations while maintaining immunogenicity. One approach is the use of short synthetic peptides that represent dominant T-cell epitopes of the allergen. Short peptides exhibit markedly reduced capacity to cross-link immunoglobulin (Ig)E and activate mast cells and basophils owing to a lack of tertiary structure. Murine preclinical studies have established the feasibility of this approach, and clinical studies are currently in progress in both allergic and autoimmune diseases.

In non-allergic individuals, allergen exposure can be associated with a failure to mount a detectable immune response. In those individuals who do make an immune response, it is characterized by non-inflammatory "regulatory" elements, such as interleukin (IL)-10-secreting T cells. ${ }^{1}$ The reasons why some individuals suffer from

Mark Larché: Department of Allergy and Clinical Immunology, Faculty of Medicine, Imperial College, South Kensington, London.

These studies were funded through grants from Asthma UK and the Medical Research Council UK.

M.L. is a shareholder in and consultant to Circassia Ltd., a company developing peptide immunotherapy for allergic and autoimmune diseases.

Correspondence to: Dr. Mark Larché, Canada Research Chair in Allergy and Immune Tolerance, Immunology and Allergy Division, Department of Medicine, McMaster University, 1200 Main Street West, Hamilton, ON L8N 3Z5; e-mail: larche@mcmaster.ca.

DOI 10.2310/7480.2007.00004 allergic diseases and others do not despite equivalent exposure are far from clear. Genetic and environmental factors influence susceptibility. Analysis of genes associated with allergic diseases suggests that susceptibility arises from a complex interaction between multiple (frequently polymorphic) genes. ${ }^{2}$

A role for environmental factors in the pathogenesis of allergic disease is demonstrated by the recent rise in the prevalence of allergic sensitization and disease in industrialized countries. Changes in sanitation, diet, vaccination practices, and other facets of modern life have been linked to increases in the prevalence of both allergic and autoimmune disease, which probably arise as a result of deficient immune regulation. ${ }^{3}$

Several populations of cells with immunoregulatory properties exist. They are important in homeostatic regulation of inflammatory responses. A number of populations of regulatory $\mathrm{T}$ cells have been characterized, including 'natural' $\mathrm{CD} 4{ }^{+} \mathrm{CD} 25^{+} \mathrm{FoxP} 3^{+}$cells and additional subsets of $\mathrm{T}$ helper (Th)3 cells producing transforming growth factor (TGF) $\beta$ and Tr1 regulatory cells producing IL-10. "Natural" regulatory T cells arise either in the thymus or peripheral lymphoid organs, whereas Th3 and Tr1 cells appear to arise from naive lymphocytes in the periphery. Deficits in the functional activity of $\mathrm{CD} 4^{+} \mathrm{CD} 25^{+}$and $\operatorname{Tr} 1$ subsets of regulatory cells have been reported in both allergic $\mathrm{c}^{5-8}$ and autoimmune $\mathrm{e}^{9-11}$ diseases.

SIT, through administration of allergen, is a form of disease-modifying treatment that has been demonstrated to be clinically efficacious in allergic rhinitis and asthma and to provide enduring clinical benefit. ${ }^{12-14}$ SIT reduces 
subsequent allergic sensitization to other allergens ${ }^{15}$ and reduces the incidence of asthma in later life. ${ }^{16,17}$ Mechanistic studies have shown down-regulation of Th2 responses in peripheral blood ${ }^{18-20}$ and/or increased Th1 responses in the tissue. ${ }^{19,21}$ SIT is also associated with the induction of allergen-specific $\operatorname{IgG}$ to allergen. ${ }^{22}$ An increased Th1 to Th2 ratio accompanied by induction of IgG initially suggested that efficacy was achieved through the induction of a "protective" Th1 responses, which antagonized Th2 allergen-specific responses. More recently, an important role for IL-10 (and in some cases TGF- $\beta$ ) has been identified. Bee keepers exposed to multiple stings may develop local allergic reactions at the beginning of the bee-keeping season, but these gradually disappear over a period of days. Protection is associated with strong allergen-specific T-cell IL-10 responses and specific IgG4. IL-10 in combination with IL-4 drives IgG4 and provides a mechanistic link between T-cell and B-cell responses. ${ }^{23}$ Several studies have recently documented increased numbers of cells expressing IL-10 (and in some cases TGF- $\beta$ ) messenger ribonucleic acid (mRNA) or protein in the peripheral blood ${ }^{24-26}$ and tissues ${ }^{27,28}$ of treated individuals. Strategies are being developed to induce regulatory cells in an antigen-specific fashion for the treatment of allergic disease and perhaps, in the future, autoimmune diseases.
Despite the efficacy of SIT, administration of wholeallergen molecules carries the risk of adverse events, which may be local or systemic and include life-threatening anaphylaxis. Considerable resources have been invested in developing strategies to reduce the allergenicity of immunotherapy preparations while maintaining their ability to modify T-cell and/or B-cell responses. One approach is to treat patients with synthetic peptides representing the immunodominant T-cell epitopes of the allergen. Short peptides have the advantage of being unable to cross-link allergen-specific IgE, leading to mast cell and basophil activation (Figure 1).

\section{Preclinical Experimental Models}

Numerous murine models have been developed of both allergic and autoimmune diseases that demonstrate the efficacy of peptide immunotherapy. Prophylactic and therapeutic protocols are effective. High-dose intravenous administration of peptide in experimental autoimmune encephalomyelitis (EAE), a model for multiple sclerosis, resulted in clonal deletion of $\mathrm{T}$ cells and protection against disease. ${ }^{29}$ Intraperitoneal administration of peptides from myelin basic protein (MBP) has also been shown to prevent EAE. ${ }^{30} \mathrm{MBP}$ peptides administered intranasally to T-cell receptor transgenic mice protected them from EAE

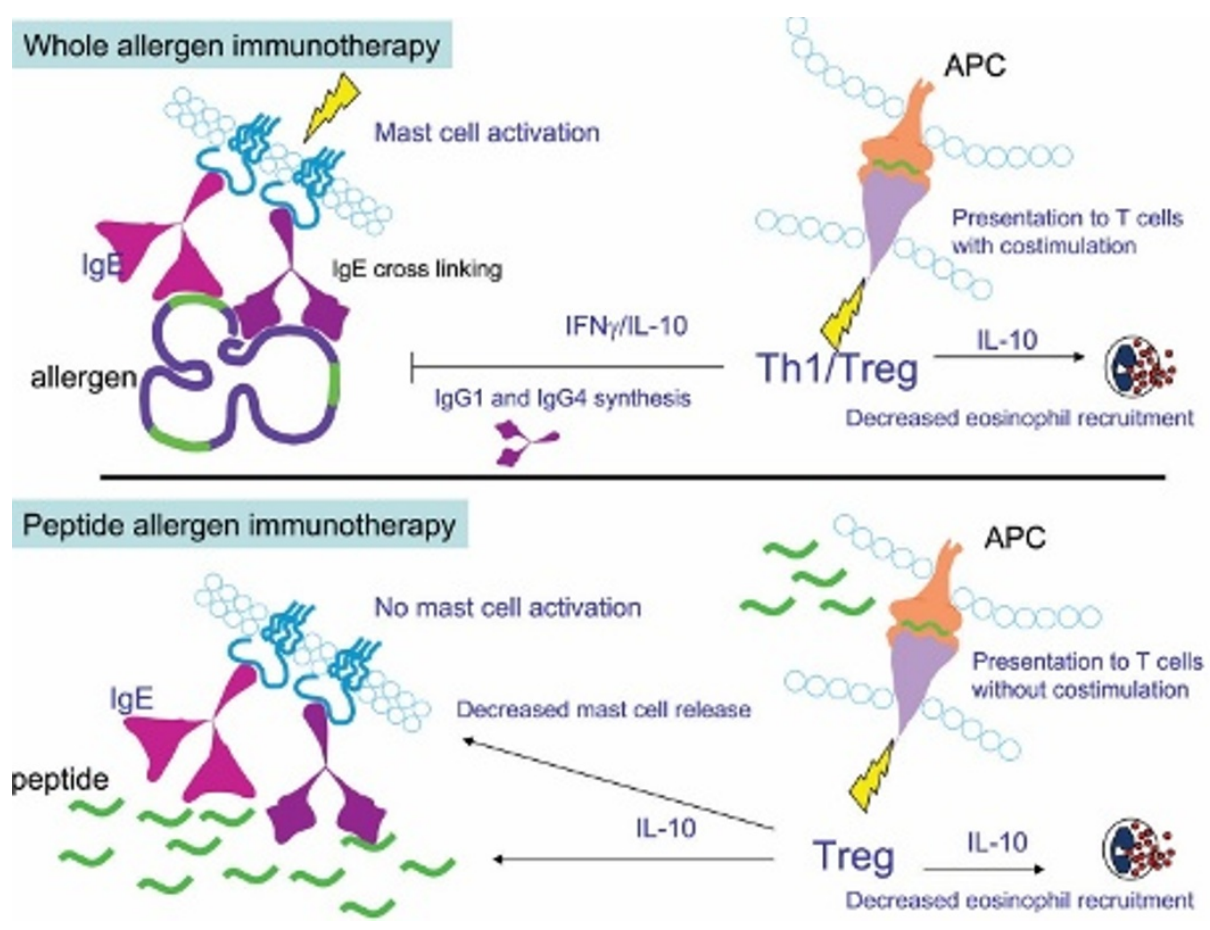

Figure 1. Comparison of wholeallergen immunotherapy and peptide immunotherapy. Whole-allergen immunotherapy leads to the generation of both $\mathrm{T}$ helper 1 (Th1) and $\mathrm{T}$ regulatory (Treg) responses. Interleukin-10 (IL-10) and interferon$\gamma($ IFN- $\gamma)$ produced by T cells of treated individuals reduce eosinophil recruitment. IL-10, IFN- $\gamma$, and IL-4 drive production of allergen-specific immunoglobulin (Ig)G antibodies. Peptides are presented to $\mathrm{T}$ cells with costimulation leading to a mixed Th1-Treg response. Whole-allergen molecules can cross-link allergen-specific IgE on the surface of mast cells and basophils, leading to cellular activation and IgEmediated adverse events. APC $=$ antigen-presenting cell. In peptide immunotherapy, short peptides do not crosslink allergen-specific IgE molecules and thus mast cells and basophils are not activated. Peptides are recognized by $\mathrm{T}$ cells in the absence of costimulation, resulting in a predominantly regulatory response characterized by IL-10, which decreases eosinophil recruitment and mast cell activation. 
in a process that was IL-10 dependent. ${ }^{31}$ Similarly, in arthritis models, peptides from type II collagen ${ }^{32,33}$ protected animals from collagen-induced arthritis, whereas peptides from the heat shock protein 60 protected mice from adjuvant arthritis. ${ }^{34}$ In diabetes models, peptides from the insulin B chain, ${ }^{35}$ glutamate decarboxylase (GAD65) ${ }^{36}$ and heat shock proteins ${ }^{37}$ have been shown to prevent the development of disease.

Peptide immunotherapy has also been evaluated in models of allergic disease. Treatment of mice sensitized to Fel d 1 with two long peptides resulted in decreased production of IL-2 and allergen-specific IgG. ${ }^{38}$ Curiously, no allergy-related end points were evaluated. Intranasal delivery of Der p 2 peptides to sensitized mice downregulated both $\mathrm{T}$-cell and antibody responses to the native protein. ${ }^{39}$ In a model of birch pollen allergy, a dominant T-cell epitope of Bet $\mathrm{v} 1$ was used to treat sensitized mice prophylactically and therapeutically following induction of allergic inflammation. ${ }^{40}$ Administration of peptides from the bee venom allergen Api $\mathrm{m} 4$ or the hornet venom allergen Dol $\mathrm{m} 5$ to mice prior to sensitization with wholevenom allergens caused a partial reduction in T-cell proliferation and antibody production. ${ }^{41}$ In separate studies, mice were protected from anaphylaxis by treatment with a mixture of three long peptides from Api m1. ${ }^{42}$

\section{Clinical Studies}

\section{Cat Allergen: Fel d 1}

Several clinical studies of therapy with peptides from Fel $\mathrm{d} 1$ have been reported in the last decade (Table 1). In four related studies, the safety and efficacy of a mixture of two long (27 amino acids each) peptides were evaluated. In the first of these, peptides were administered subcutaneously to 95 cat-allergic subjects at weekly intervals at three doses (7.5, 75, and $750 \mu \mathrm{g}$ per injection) $){ }^{43}$ At higher doses, improvements in lung and nasal symptom scores were observed. However, treatment was associated with frequent adverse events occurring minutes to hours after

Table 1. Clinical studies of peptide immunotherapy in allergy.

\begin{tabular}{|c|c|c|c|c|c|c|c|}
\hline Allergen & $\begin{array}{c}\text { Peptide } \\
\text { Characteristics }\end{array}$ & Study Design & $\begin{array}{l}\text { Number of } \\
\text { Subjects }\end{array}$ & $\begin{array}{c}\text { Route of } \\
\text { Administration }\end{array}$ & Total Dose $(\mu g)$ & Clinical Outcomes & Reference \\
\hline \multirow[t]{9}{*}{ Fel d 1 (cat) } & $2 \times 27$ mer & DBPC & 95 & SC & $30-3,000$ & $\begin{array}{l}\text { Nasal and lung } \\
\text { symptoms }\end{array}$ & 43 \\
\hline & $2 \times 27 \mathrm{mer}$ & Open & & SC & $150-4,500$ & Allergen $\mathrm{PD}_{20}$ & 46 \\
\hline & $2 \times 27 \mathrm{mer}$ & DBPC & 42 & SC & 1,000 & $\begin{array}{l}\text { End-point titration, } \\
\text { skin LPR }\end{array}$ & 47 \\
\hline & $2 \times 27 \mathrm{mer}$ & DBPC & 133 & SC & $600-6,000$ & $\begin{array}{l}\mathrm{FEV}_{1},{ }^{*} \text { daily peak flow, } \\
\text { skin EPR, symptom } \\
\text { assessment }\end{array}$ & 48 \\
\hline & $3 \times 16 / 17 \mathrm{mer}$ & Open & 6 & ID & 80 & Isolated LAR & 44 \\
\hline & $12 \times 16 / 17$ mer & Open & 8 & ID & 5 & $\begin{array}{l}\text { Isolated LAR and skin } \\
\text { LPR }\end{array}$ & 49 \\
\hline & $12 \times 16 / 17 \mathrm{mer}$ & DBPC & 24 & ID & 90 & $\begin{array}{l}\text { Skin LPR and EPR, } \\
\mathrm{PC}_{20}, \mathrm{PD}_{20}\end{array}$ & 50 \\
\hline & $11 \times 16 / 17$ mer & Open & 8 & ID & 41.1 & Skin LPR, $\mathrm{PC}_{20}$ & 51 \\
\hline & $12 \times 16 / 17 \mathrm{mer}$ & DBPC/open & 28 & ID & $216-341$ & $\begin{array}{l}\text { Nasal allergen } \\
\text { challenge, bronchial } \\
\text { challenge, skin LPR }\end{array}$ & 53 \\
\hline \multirow[t]{3}{*}{$\begin{array}{l}\text { Api m } 1\left(\mathrm{PLA}_{2}\right) \\
\text { (bee) }\end{array}$} & $\begin{array}{l}1 \times 11,1 \times 12,1 \\
\quad \times 18\end{array}$ & Open & 5 & SC & 397.1 & $\begin{array}{l}\text { Skin challenge } \text { PLA }_{2} \text {, } \\
\text { bee sting }\end{array}$ & 55 \\
\hline & $\begin{array}{l}1 \times 60,1 \times 53,1 \\
\quad \times 45\end{array}$ & DBPC & 16 & SC & 751.1 & $\begin{array}{l}\text { End-point skin } \\
\text { titration }\end{array}$ & 58 \\
\hline & $4 \times 18$ & $\begin{array}{l}\text { Open- } \\
\text { controlled }\end{array}$ & 24 & ID & 431.1 & Skin LPR & 57 \\
\hline
\end{tabular}

$\mathrm{DBPC}=$ double-blind placebo controlled; $\mathrm{EPR}=$ early-phase reaction; $\mathrm{FEV}_{1}=$ forced expiratory volume in 1 second; ID $=$ intradermal; LAR $=$ late asthmatic reaction; $\mathrm{LPR}=$ late-phase reaction; $\mathrm{PC}_{20}=$ provocative concentration of histamine that induces a $20 \%$ reduction in $\mathrm{FEV}_{1} ; \mathrm{PD}_{20}=$ provocative dose of inhaled allergen resulting in a $20 \%$ reduction in forced expiratory volume in 1 second; $\mathrm{PLA}_{2}=$ phospholipase $\mathrm{A}_{2}$; SC $=$ subcutaneous. *Only in subjects with reduced baseline $\mathrm{FEV}_{1}$ and only at one time point. 
peptide administration. Immediate reactions appeared to be IgE mediated and may have arisen as a result of crosslinking pre-existing peptide-specific IgE present in some patients or through the development of de novo peptidespecific IgE, as observed in others. The relatively large peptides employed (27 amino acids) may have retained conformational IgE epitopes or formed dimmers through disulphide binding. Later adverse events included what may have been isolated late asthmatic reactions, which were later characterized in detail. ${ }^{44}$ Related in vitro studies showed reduced IL-4 production in peptide-specific T-cell lines in vitro following therapy. ${ }^{45}$

A further study evaluated allergen sensitivity by inhaled challenge of allergic asthmatic subjects before and after peptide therapy. Again, three dosage groups were used. Treatment was also associated with reduced allergen $\mathrm{PD}_{20}$ (provocative dose of inhaled allergen resulting in a $20 \%$ reduction in forced expiratory volume in 1 second $\left[\mathrm{FEV}_{1}\right]$ ) in the high-dose and medium-dose groups, together with reduced allergen-induced IL-4 production from peripheral blood mononuclear cells (PBMCs). ${ }^{46}$

Not all studies demonstrate a positive clinical response. Peptides or placebo was administered weekly by subcutaneous injection (four doses of $250 \mu \mathrm{g}$ ) to 42 subjects with cat-allergic rhinitis and/or asthma. ${ }^{47}$ Treatment was associated with frequent adverse events, mostly respiratory in nature. PBMC cytokine secretion patterns were not different in peptide-treated and placebo-treated subjects. No changes in allergen-induced early- and late-phase skin responses were observed.

In the largest of the four studies, 133 cat-allergic subjects received eight subcutaneous injections of $750 \mu \mathrm{g}$ of the peptide mixture. The only significant clinical outcome was observed in a secondary analysis as an improvement in pulmonary function observed in individuals with reduced baseline $\mathrm{FEV}_{1}$; the improvement was evident only at a single time point (3 weeks). Adverse events were common as in the other related studies. ${ }^{48}$

More recently, studies have been performed using mixtures of shorter peptides from Fel d 1. ${ }^{44,49-54}$ Peptides were administered intradermally to cat-allergic asthmatic subjects of mild to moderate disease severity. Treatment with a single dose ( $5 \mu \mathrm{g}$ of each peptide in a mixture) resulted in significant reductions in the magnitude of the cutaneous late-phase reaction to intradermal allergen challenge. PBMC cultures stimulated with allergen in vitro demonstrated reductions in both Th1 and Th2 cytokines. ${ }^{49}$

Subsequently, in a double-blind, placebo-controlled study, 24 cat-allergic asthmatic subjects were treated with incremental, divided doses of peptides (total dose $90 \mu \mathrm{g}$ of each peptide). ${ }^{50}$ Treatment resulted in a significant reduction in both early- and late-phase cutaneous reactions to allergen challenge when compared with placebo. Proliferative responses and Th1 and Th2 cytokine production from PBMCs cultured with allergen were also reduced in the active treatment group. Additionally, levels of IL-10 production were increased. Peptide treatment resulted in a significantly improved ability to tolerate exposure to cats after therapy. No significant improvements were observed in $\mathrm{PD}_{20}$ or $\mathrm{PC}_{20}$.

In a small open-label study using a similar peptide preparation delivered at 2-week intervals rather than 3- to 4-day intervals, a significant improvement in $\mathrm{PC}_{20}$ was observed. ${ }^{51}$ Peptides were given by intradermal injection with a 2-week interval and a lower total dose of peptide was administered ( $41.1 \mu \mathrm{g}$ of each peptide). The cutaneous late-phase reaction was significantly reduced following allergen challenge in the skin. Significantly more CD $25^{+}$ cells were found in allergen challenge skin sites from peptide-treated subjects compared with placebo. The number of $\mathrm{CD}^{+} / \mathrm{IFN}-\gamma^{+}$cells also increased, suggesting that recruitment of Th1 cells to the skin may play a role in modifying the Th1:Th2 balance in the response to allergen. No increases in IL- $10^{+}$cells were observed in the skin, but expression of TGF- $\beta$ mRNA was increased.

Modulation of $\mathrm{CD} 4^{+} \mathrm{CD} 25^{+}$regulatory T-cell function has been evaluated in allergen-stimulated cultures in a double-blind, placebo-controlled trial of peptide immunotherapy. ${ }^{52}$ Proliferative responses and IL-13 production from PBMCs cultured with allergen in vitro were significantly reduced following peptide therapy as in previous studies. However, no improvement in the suppressive activity of $\mathrm{CD}^{+} \mathrm{CD} 25^{+}$cells was observed. Thus, $\mathrm{CD} 4^{+} \mathrm{CD} 25^{+}$regulatory $\mathrm{T}$ cells may not play a significant role in the mechanism of action of peptide immunotherapy.

The effect of peptide therapy on non- $\mathrm{CD} 4^{+} \mathrm{CD} 25^{+}$ regulatory $\mathrm{T}$ cells was also investigated. The induction of allergen-specific "inducible" regulatory $\mathrm{T}$ cells was addressed by mixing $\mathrm{CD} 4^{+} \mathrm{T}$ cells with $\mathrm{CD} 4^{-}$cells before and after therapy. ${ }^{54}$ The results demonstrated that $\mathrm{CD} 4^{+}$ cells isolated after therapy could suppress the proliferative response of baseline $\mathrm{CD}^{-}$cells. These data provide evidence that peptide immunotherapy induces a population of $\mathrm{CD}^{+} \mathrm{T}$ cells with allergen-specific regulatory or suppressive activity.

\section{Insect Venom Allergy: Api m1}

Fewer clinical studies have been reported with peptides from the major bee venom allergen Api m1 (phospholipase 
$A_{2}$ ). In a small open study, five bee venom-allergic subjects received subcutaneous incremental doses of a mixture of three immunodominant peptides at weekly intervals. ${ }^{55}$ The cumulative peptide dose was $397.1 \mu \mathrm{g}$, with a first dose of $0.1 \mu \mathrm{g}$ building to a final series of maintenance doses of $100 \mu \mathrm{g}$. One week after completion of peptide dosing, subjects were challenged by subcutaneous administration of $10 \mu \mathrm{g}$ of whole Api m 1. All subjects tolerated Api m 1 challenge without systemic allergic symptoms. One week later, a bee sting challenge was performed. Three individuals tolerated the challenge without any allergic sequelae; the remaining two subjects developed mild systemic allergic reactions. Levels of allergen-specific serum IgE or IgG4 did not change during the course of peptide therapy. However, following subcutaneous challenge with Api m 11 week after the last peptide injection, concentrations of both isotypes, in particular IgG4, increased markedly.

Immunodominant $\mathrm{T}$-cell epitopes have been defined by direct peptide-major histocompatibility complex (MHC) binding studies in Api $\mathrm{m} 1$ by direct binding of peptides to purified MHC class II molecules. Four dominant peptides were identified; three of these represented similar regions of the molecule to those employed previously. ${ }^{56}$ These four peptides were evaluated in a controlled, open-label, singleblind study in subjects with mild bee venom allergy. ${ }^{57}$ Treatment was well tolerated, with no allergic reactions observed. Proliferation of $\mathrm{T}$ cells to purified allergen and whole bee venom was significantly reduced after therapy. Proliferative responses to treatment peptides were also reduced. Th2 cytokine production following culture with allergen was reduced but associated with a concomitant increase in IL-10. Cutaneous late-phase reactions to challenge with whole bee venom or Api $\mathrm{m} 1$ were significantly reduced. Allergen-specific IgG and IgE levels were measured, revealing a significant, transient increase in allergen-specific IgG and IgG4 following peptide immunotherapy.

RUSH desensitization was employed to treat bee venom-allergic subjects using three synthetic polypeptides spanning the whole Api $\mathrm{m} 1$ molecule. ${ }^{58}$ Patients received approximately $250 \mu \mathrm{g}$ of each peptide in incremental doses at 30-minute intervals starting with $0.1 \mu \mathrm{g}$. Maintenance injections of $100 \mu \mathrm{g}$ (in some cases $300 \mu \mathrm{g}$ ) were given on days $4,7,14,42$, and 70 . T-cell proliferation increased transiently during therapy in the active treatment group. IFN- $\gamma$ and IL-10 levels but not Th2 cytokines increased. Allergen-specific IgG4 but not IgE levels increased throughout the study period. Peptide-specific IgE was induced in some patients during the study. Skin sensitivity to intradermal allergen challenge did not change significantly. Peptide therapy was generally well tolerated. However, local and disseminated erythema with occasional hand palm pruritus was observed in two subjects at higher doses.

In conclusion, peptide immunotherapy has been shown to improve clinical outcomes and surrogate markers in a variety of studies. Treatment appears to be associated with the induction of IL-10 and a population of allergenspecific regulatory or suppressor T cells. Numerous studies in both allergic and autoimmune diseases support the potential of this approach. However, significant issues still need to be addressed, including whether delivery of T-cell epitopes without competent B-cell epitopes will be sufficient to provide efficacy equivalent to conventional, whole-allergen immunotherapy. Short peptides (less than 20 amino acids) appear to have markedly reduced ability to cross-link allergen-specific IgE and are less allergenic than the whole molecule. However, delivery of high doses of peptide may activate memory effector $\mathrm{T}$ cells, resulting in $\mathrm{T}$ cell-mediated events such as isolated late asthmatic reactions. Recent data suggest that such reactions can be avoided with lower peptide doses, which are still capable of inducing tolerance. Care must be taken in peptide selection to ensure full population coverage based on the MHC-binding characteristics of the peptides. In practice, one peptide can contain several overlapping T-cell epitopes with affinity for a range of MHC molecules. Further clinical studies are required with preparations of short peptides derived from the sequences of other allergens.

\section{Acknowledgements}

I am grateful to the following individuals who contributed to the studies reviewed in this article: A.B. Kay, B.M. Haselden, W.L.G. Oldfield, C. Alexander, M. Tarzi, T.F. Smith, K. Shirley, J. Arbery, A. Verhoef, J. Barkans, and S. Ying.

\section{References}

1. Akdis M, Verhagen J, Taylor A, et al. Immune responses in healthy and allergic individuals are characterized by a fine balance between allergen-specific T regulatory 1 and T helper 2 cells. J Exp Med 2004;199:1567-75.

2. Cookson W. Genetics and genomics of asthma and allergic diseases. Immunol Rev 2002;190:195-206.

3. Gale EA. A missing link in the hygiene hypothesis? Diabetologia 2002;45:588-94.

4. Wraith DC, Nicolson KS, Whitley NT. Regulatory CD4(+) T cells and the control of autoimmune disease. Curr Opin Immunol 2004; 16:695-701. 
5. Ling EM, Smith T, Nguyen XD, et al. Relation of CD4+CD25+ regulatory $\mathrm{T}$-cell suppression of allergen-driven $\mathrm{T}$-cell activation to atopic status and expression of allergic disease. Lancet 2004;363: 608-15.

6. Verhagen J, Akdis M, Traidl-Hoffmann C, et al. Absence of Tregulatory cell expression and function in atopic dermatitis skin. J Allergy Clin Immunol 2006;117:176-83.

7. Karlsson MR, Rugtveit J, Brandtzaeg P. Allergen-responsive $\mathrm{CD} 4+\mathrm{CD} 25+$ regulatory $\mathrm{T}$ cells in children who have outgrown cow's milk allergy. J Exp Med 2004;199:1679-88.

8. Ou LS, Goleva E, Hall C, Leung DY. T regulatory cells in atopic dermatitis and subversion of their activity by superantigens. J Allergy Clin Immunol 2004;113:756-63.

9. de Kleer IM, Wedderburn LR, Taams LS, et al. CD4+CD25 bright regulatory $\mathrm{T}$ cells actively regulate inflammation in the joints of patients with the remitting form of juvenile idiopathic arthritis. J Immunol 2004;172:6435-43.

10. Arif S, Tree TI, Astill TP, et al. Autoreactive T cell responses show proinflammatory polarization in diabetes but a regulatory phenotype in health. J Clin Invest 2004;113:451-63.

11. Balandina A, Lecart S, Dartevelle P, et al. Functional defect of regulatory $\mathrm{CD} 4+\mathrm{CD} 25+\mathrm{T}$ cells in the thymus of patients with autoimmune myasthenia gravis. Blood 2005;105:735-41.

12. Bousquet J, Lockey R, Malling HJ. Allergen immunotherapy: therapeutic vaccines for allergic diseases. A WHO position paper. J Allergy Clin Immunol 1998;102(4 Pt 1):558-62.

13. Abramson M, Puy R, Weiner J. Immunotherapy in asthma: an updated systematic review. Allergy 1999;54:1022-41.

14. Durham SR, Walker SM, Varga EM, et al. Long-term clinical efficacy of grass-pollen immunotherapy. N Engl J Med 1999;341: $468-75$.

15. Pajno GB, Barberio G, De Luca F, et al. Prevention of new sensitizations in asthmatic children monosensitized to house dust mite by specific immunotherapy. A six-year follow-up study. Clin Exp Allergy 2001;31:1392-7.

16. Moller C, Dreborg S, Ferdousi HA, et al. Pollen immunotherapy reduces the development of asthma in children with seasonal rhinoconjunctivitis (the PAT-study). J Allergy Clin Immunol 2002; 109:251-6.

17. Polosa R, Al Delaimy WK, Russo C, et al. Greater risk of incident asthma cases in adults with allergic rhinitis and effect of allergen immunotherapy: a retrospective cohort study. Respir Res 2005;6: 153.

18. Secrist $\mathrm{H}$, Chelen CJ, Wen $\mathrm{Y}$, et al. Allergen immunotherapy decreases interleukin 4 production in $\mathrm{CD} 4+\mathrm{T}$ cells from allergic individuals. J Exp Med 1993;178:2123-30.

19. Varney VA, Hamid QA, Gaga M, et al. Influence of grass pollen immunotherapy on cellular infiltration and cytokine mRNA expression during allergen-induced late-phase cutaneous responses. J Clin Invest 1993;92:644-51.

20. Ebner C, Siemann U, Bohle B, et al. Immunological changes during specific immunotherapy of grass pollen allergy: reduced lymphoproliferative responses to allergen and shift from $\mathrm{TH} 2$ to $\mathrm{TH} 1$ in $\mathrm{T}$ cell clones specific for $\mathrm{Phl} \mathrm{p} \mathrm{1,} \mathrm{a} \mathrm{major} \mathrm{grass} \mathrm{pollen} \mathrm{allergen.} \mathrm{Clin}$ Exp Allergy 1997;27:1007-15.

21. Wachholz PA, Nouri-Aria KT, Wilson DR, et al. Grass pollen immunotherapy for hayfever is associated with increases in local nasal but not peripheral Th1:Th2 cytokine ratios. Immunology 2002;105:56-62.
22. Aalberse RC, van der GR, van Leeuwen J. Serologic aspects of IgG4 antibodies. I. Prolonged immunization results in an IgG4restricted response. J Immunol 1983;130:722-6.

23. Jeannin $\mathrm{P}$, Lecoanet $\mathrm{S}$, Delneste $\mathrm{Y}$, et al. IgE versus IgG4 production can be differentially regulated by IL-10. J Immunol 1998;160:3555-61.

24. Jutel M, Akdis M, Budak F, et al. IL-10 and TGF-beta cooperate in the regulatory $\mathrm{T}$ cell response to mucosal allergens in normal immunity and specific immunotherapy. Eur J Immunol 2003;33: 1205-14.

25. Akdis CA, Akdis M, Blesken T, et al. Epitope-specific $\mathrm{T}$ cell tolerance to phospholipase A2 in bee venom immunotherapy and recovery by IL-2 and IL-15 in vitro. J Clin Invest 1996;98: 1676-83.

26. Francis JN, Till SJ, Durham SR. Induction of IL-10+CD4+CD25+ $\mathrm{T}$ cells by grass pollen immunotherapy. J Allergy Clin Immunol 2003;111:1255-61.

27. Nouri-Aria KT, Wachholz PA, Francis JN, et al. Grass pollen immunotherapy induces mucosal and peripheral IL-10 responses and blocking IgG activity. J Immunol 2004;172:3252-9.

28. Nasser S, Ying S, Meng Q, et al. Interleukin 10 levels increase in cutaneous biopsies of patients undergoing venom immunotherapy. Eur J Immunol 2001;31:3704-13.

29. Critchfield JM, Racke MK, Zuniga-Pflucker JC, et al. T cell deletion in high antigen dose therapy of autoimmune encephalomyelitis. Science 1994;263:1139-43.

30. Gaur A, Wiers B, Liu A, et al. Amelioration of autoimmune encephalomyelitis by myelin basic protein synthetic peptideinduced anergy. Science 1992;258:1491-4.

31. Burkhart C, Liu GY, Anderton SM, et al. Peptide-induced T cell regulation of experimental autoimmune encephalomyelitis: a role for IL-10. Int Immunol 1999;11:1625-34.

32. $\mathrm{Ku} \mathrm{G}$, Kronenberg $\mathrm{M}$, Peacock DJ, et al. Prevention of experimental autoimmune arthritis with a peptide fragment of type II collagen. Eur J Immunol 1993;23:591-9.

33. Staines NA, Harper N, Ward FJ, et al. Mucosal tolerance and suppression of collagen-induced arthritis (CIA) induced by nasal inhalation of synthetic peptide 184-198 of bovine type II collagen (CII) expressing a dominant $\mathrm{T}$ cell epitope. Clin Exp Immunol 1996;103:368-75.

34. Prakken BJ, van Der ZR, Anderton SM, et al. Peptide-induced nasal tolerance for a mycobacterial heat shock protein $60 \mathrm{~T}$ cell epitope in rats suppresses both adjuvant arthritis and nonmicrobially induced experimental arthritis. Proc Natl Acad Sci U S A 1997;94:3284-9.

35. Daniel D, Wegmann DR. Protection of nonobese diabetic mice from diabetes by intranasal or subcutaneous administration of insulin peptide B-(9-23). Proc Natl Acad Sci U S A 1996;93:95660.

36. Tian J, Atkinson MA, Clare-Salzler M, et al. Nasal administration of glutamate decarboxylase (GAD65) peptides induces Th2 responses and prevents murine insulin-dependent diabetes. J Exp Med 1996;183:1561-7.

37. Bockova J, Elias D, Cohen IR. Treatment of NOD diabetes with a novel peptide of the hsp60 molecule induces Th2-type antibodies. J Autoimmun 1997;10:323-9.

38. Briner TJ, Kuo MC, Keating KM, et al. Peripheral T-cell tolerance induced in naive and primed mice by subcutaneous injection of 
peptides from the major cat allergen Fel d I. Proc Natl Acad Sci U S A 1993;90:7608-12.

39. Hoyne GF, O'Hehir RE, Wraith DC, et al. Inhibition of T cell and antibody responses to house dust mite allergen by inhalation of the dominant T cell epitope in naive and sensitized mice. J Exp Med 1993;178:1783-8.

40. Bauer L, Bohle B, Jahn-Schmid B, et al. Modulation of the allergic immune response in $\mathrm{BALB} / \mathrm{c}$ mice by subcutaneous injection of high doses of the dominant $\mathrm{T}$ cell epitope from the major birch pollen allergen Bet v 1. Clin Exp Immunol 1997;107:536-41.

41. King TP, Lu G, Agosto H. Antibody responses to bee melittin (Api $\mathrm{m} \mathrm{4}$ ) and hornet antigen 5 (Dol m 5) in mice treated with the dominant T-cell epitope peptides. J Allergy Clin Immunol 1998; 101:397-403.

42. von Garnier C, Astori M, Kettner A, et al. Allergen-derived long peptide immunotherapy down-regulates specific IgE response and protects from anaphylaxis. Eur J Immunol 2000;30:1638-45.

43. Norman PS, Ohman JL, Long AA, et al. Treatment of cat allergy with T-cell reactive peptides. Am J Respir Crit Care Med 1996; 154(6 Pt 1):1623-8.

44. Haselden BM, Kay AB, Larche M. Immunoglobulin E-independent major histocompatibility complex-restricted $\mathrm{T}$ cell peptide epitope-induced late asthmatic reactions. J Exp Med 1999;189:188594.

45. Marcotte GV, Braun CM, Norman PS, et al. Effects of peptide therapy on ex vivo T-cell responses. J Allergy Clin Immunol 1998; 101(4 Pt 1):506-13.

46. Pene J, Desroches A, Paradis L, et al. Immunotherapy with Fel d 1 peptides decreases IL-4 release by peripheral blood T cells of patients allergic to cats. J Allergy Clin Immunol 1998;102(4 Pt 1): 571-8.

47. Simons FE, Imada M, Li Y, et al. Fel d 1 peptides: effect on skin tests and cytokine synthesis in cat-allergic human subjects. Int Immunol 1996;8:1937-45.

48. Maguire P, Nicodemus C, Robinson D, et al. The safety and efficacy of ALLERVAX CAT in cat allergic patients. Clin Immunol 1999;93:222-31.
49. Oldfield WL, Kay AB, Larche M. Allergen-derived T cell peptideinduced late asthmatic reactions precede the induction of antigenspecific hyporesponsiveness in atopic allergic asthmatic subjects. J Immunol 2001;167:1734-9.

50. Oldfield WL, Larche M, Kay AB. Effect of T-cell peptides derived from Fel $\mathrm{d} 1$ on allergic reactions and cytokine production in patients sensitive to cats: a randomised controlled trial. Lancet 2002;360:47-53.

51. Alexander C, Ying S, Kay B, Larche M. Fel d 1-derived T cell peptide therapy induces recruitment of $\mathrm{CD} 4 \mathrm{CD} 25$; CD4 interferon-gamma $\mathrm{T}$ helper type 1 cells to sites of allergen-induced latephase skin reactions in cat-allergic subjects. Clin Exp Allergy 2005; 35:52-8.

52. Smith TR, Alexander C, Kay AB, et al. Cat allergen peptide immunotherapy reduces CD4 $\mathrm{T}$ cell responses to cat allergen but does not alter suppression by CD4 CD25 T cells: a double-blind placebo-controlled study. Allergy 2004;59:1097-101.

53. Alexander C, Tarzi M, Larche M, Kay AB. The effect of Fel d 1derived T-cell peptides on upper and lower airway outcome measurements in cat-allergic subjects. Allergy 2005;60:1269-74.

54. Verhoef A, Alexander C, Kay AB, Larche M. T cell epitope immunotherapy induces a $\mathrm{CD} 4(+) \mathrm{T}$ cell population with regulatory activity. PLoS Med 2005;2:e78.

55. Muller U, Akdis CA, Fricker M, et al. Successful immunotherapy with T-cell epitope peptides of bee venom phospholipase A2 induces specific T-cell anergy in patients allergic to bee venom. J Allergy Clin Immunol 1998;101(6 Pt 1):747-54.

56. Texier C, Pouvelle S, Busson M, et al. HLA-DR restricted peptide candidates for bee venom immunotherapy. J Immunol 2000;164: 3177-84.

57. Tarzi M, Klunker S, Texier C, et al. Induction of interleukin-10 and suppressor of cytokine signalling-3 gene expression following peptide immunotherapy. Clin Exp Allergy 2006;36:465-74.

58. Fellrath JM, Kettner A, Dufour N, et al. Allergen-specific T-cell tolerance induction with allergen-derived long synthetic peptides: results of a phase I trial. J Allergy Clin Immunol 2003;111:85461. 